\title{
Use of Operating Theatre Background Music: Opinion of Patients
}

\author{
Rex Friday Ogoronte A. Ijah, Friday E. Aaron, Solomon N. Elenwo, Joy O. Dayi, \\ Vitalis O. Ofuru, and Rose E. Oko-Jaja
}

\section{ABSTRACT}

\begin{abstract}
Aim: To determine the opinion of patients on the use of operating theatre background music in tertiary health care facilities in Port Harcourt.

Background: Music finds application in almost all spheres of society due to some beneficial effects. It has been used among patients in the intensive care setting, among hypertensives with associated lowering the systolic blood pressure, among endoscopy patients with significantly improved pain score and significantly reduced anxiety, for pain relief and relaxation, and also for expectant mothers in labour.
\end{abstract}

Materials and Methods: The cross-sectional descriptive study was carried out among patients from March to June 2020 in two multispecialty tertiary healthcare facilities in Port Harcourt Nigeria. Using semi-structured questionnaires and convenience sampling method, 425 respondents were recruited. Data collected was analysed using the Statistical Package for the Social Sciences (SPSS) version 20.0.

Results: Four hundred and two $(\mathbf{9 4 . 6 \% )}$ respondents loved listening to music at home. Two hundred and seventy-three $(64.2 \%)$ respondents preferred to listen to music in operating theatre. Preference for timing of music usage in theatre was variable: before, during and after surgery. One hundred and forty-four (33.9\%) respondents asserted that they would love to listen to music in theatre during surgery. Two hundred and thirty-three $\mathbf{5 5 . 5 \% )}$ respondents asserted that there was no background music during their last surgery.

Conclusion: Majority of patients were desirous of the use of music in the operating theatre, while a few others thought otherwise.

Keywords: Background Music, Nigeria, Operating Theatre, Opinion of Patients, Port Harcourt, Tertiary Healthcare.

\section{INTRODUCTION}

The Biblical story of the playing of music by David to calm "frayed nerves" of King Saul is a ready example of the use of music in society [1], [2]. Music finds application in almost all spheres of society: music and audiovisual media [3], [4]; among the rich and the poor; among the aged and in lullaby for children [5]-[8]; among kings and servants; in military parade and wartime martial music [9]-[11], and in sober mood of religious worship [12]-[14]. Music also find expression in homes [15], [16], and for public entertainment like world sporting competitions [17], [18], to mention but a few. Music can be used to convey some messages and carry along with it some emotions [19], and for cultural identity [20]-[23].

There are different types of music for different purposes, and individual differences exist in their appreciation of music.
Submitted: February 10, 2021

Published: August 11, 2021

ISSN: $2593-8339$

DOI: $10.24018 /$ ejmed.2021.3.4.716

Rex Friday Ogoronte A. Ijah*

Department of Surgery, University of Port Harcourt Teaching Hospital, Port Harcourt, Nigeria.

(e-mail: rexijah@ gmail.com)

Friday E. Aaron

Department of Surgery, Rivers State University Teaching Hospital, Port Harcourt, and Senior Lecturer, University of Port Harcourt, Port Harcourt, Nigeria.

Solomon N. Elenwo

Department of Surgery, University of Port Harcourt Teaching Hospital, Port Harcourt, Nigeria.

Joy O. Dayi

Department of Anaesthesia, University of Port Harcourt Teaching Hospital, Port Harcourt, Nigeria.

Vitalis O. Ofuru

Department of Surgery, University of Port Harcourt Teaching Hospital, Port Harcourt, Nigeria.

Rose E. Oko-Jaja

Department of Nursing Services, University of Port Harcourt Teaching Hospital, Port Harcourt, Nigeria.

*Corresponding Author
Out of the four key human temperaments, individuals with melancholic temperament or a blend thereof are said to like music more than others [24], [25]. Music preferences exist, with some music types tagged more distracting on cognitive function and task performance. A study compared the effect of Mozart classical and rock music on listening comprehension and found no significant difference [26]. However, there are many other studies whose findings fall on both sides of the divide. Music that does not distract a listener from the focus of activity is considered background, and the non-distracting property of this music has been explored in many environments with favorable results [27]-[30].

Though the mechanism of effects is not very clear, reduction in stress response and hence reduction in plasma stress hormone levels has been reported following use of music [31]. Mention has been made of the hypothalamicpituitary axis, the sympathetic nervous system, and the 
immune system, as possible pathway through which music exerts effect on metabolism and energy balance [32], [33]. Another mechanism through which music is said to act is through increase in calcium / CaM-dependent dopamine synthesis in the brain, thus causing a reduction in blood pressure [34]. Also, among the suggested mechanism is the integrative role for complex cortical processes with longexisting reinforcement circuits, and an interaction between sensory processing and decoding mechanisms and affective processing [35].

In this study, the research questions were: does operating theatre background music have any role in healthcare service delivery in modern times? What opinions/perceptions do patients hold on the use of operating theatre background music in our tertiary health care facilities in Port Harcourt? This study was therefore set out to determine opinion of patients on the role of operating theatre background music on patients in tertiary health care facilities in Port Harcourt.

\section{Methodology}

\section{A. Study Area}

The study was carried in Port Harcourt the capital of Rivers State, Nigeria.

\section{B. Study Place and Period}

The specialist surgical outpatient clinics and wards of the University of Port Harcourt Teaching Hospital (UPTH) and the Rivers State University Teaching Hospital (RSUTH) in Port Harcourt were the places the study was carried out, between March 2020 and June 2020.

\section{Study Design}

A cross-sectional descriptive study.

\section{Study Population}

Surgical patients in the two tertiary health care facilities constituted the study population.

\section{E. Sample Size Determination}

Four hundred was the calculated minimum sample size determined using the formula developed by Yaro Yamen for survey. It was based on estimated population of 10,000 surgical patients. Using the formula:

$$
\mathrm{n}=\mathrm{N} /\left(1+\mathrm{Ne}^{2}\right)
$$

where $\mathrm{n}=$ minimum sample size, $\mathrm{N}=$ Total population size and $\mathrm{e}=$ desired precision/level of significance, usually $5 \%$ $(0.05)$ at $95 \%$ Confidence Interval (CI). Four hundred and twenty-five (425) respondents were recruited.

\section{F. Sampling Technique Procedure}

Convenience sampling method was used.

\section{G. Data Analysis}

Information on socio-demographic characteristics; role, knowledge, uses of music; perception of patients on operating theatre background music, were collated and analyzed using the Statistical Package for the Social Sciences (SPSS) version 20.0 .

\section{RESUlTS}

A total of 425 respondents participated in the study. The demographic characteristics of the respondents presented in Table I indicated that $289(68.0 \%)$ were females while 136 $(32.0 \%)$ were males. Two hundred and fifty-one (59.1\%) respondents were between 25 and 40 years of age. The role, knowledge and uses of music outside hospital setting among the respondents was assessed and presented Table II. Four hundred and two $(94.6 \%)$ respondents loved listening to music at home. Music preferences of respondents were 75 $(17.6 \%)$ - classical music, 123 (28.9\%) - hymns, 119 $(28.0 \%)$ - soft music like "blues". Two hundred and thirtythree $(54.8 \%)$ respondents felt that music is useful for relaxation, $112(26.4 \%)$ for meditation, $8(1.9 \%)$ for reading, and $28(6.6 \%)$ for work.

TABLE I: SOCIO-DEMOGRAPHIC CHARACTERISTICS OF PATIENT

\begin{tabular}{ccc}
\multicolumn{3}{c}{ ResPONDENTS $(\mathrm{N}=425)$} \\
\hline \multicolumn{1}{c}{ Variables } & Frequency & Percentage \\
Sex & 136 & 32.0 \\
Male & 289 & 68.0 \\
Female & & \\
Age & 64 & 15.1 \\
$\quad$ Less than 25 years & 251 & 59.1 \\
25-40 Years & 85 & 20.0 \\
41-60 years & 25 & 5.9 \\
$\quad$ Above 60 years & 151 & \\
Marital Status & 270 & 35.5 \\
$\quad$ Single & 4 & 63.5 \\
Married & & .9 \\
Divorced & 420 & 98.8 \\
Religion & 5 & 1.2 \\
Christianity & & \\
Islam &
\end{tabular}

\begin{tabular}{lcc}
\multicolumn{3}{c}{ TABLE II: KNOWLEDGE/USES OF MUSIC OUTSIDE HOSPITAL SETTING (N=425) } \\
\hline \multicolumn{1}{c}{ Variables } & Frequency & Percentage \\
\hline $\begin{array}{l}\text { Love listening to music at home } \\
\text { Yes }\end{array}$ & 402 & 94.6 \\
No & 10 & 2.4 \\
Don't know & 13 & 3.1 \\
Kind of music prefer outside ceremonial & & \\
occasions & & \\
Classical music & 75 & 17.6 \\
Hymns & 123 & 28.9 \\
Contemporaries & 25 & 5.9 \\
Country music & 24 & 5.6 \\
Soft music (Blues) & 119 & 28.0 \\
Native Songs & 38 & 8.9 \\
Praise and worship songs & 21 & 4.9 \\
Music usefulness & & \\
For relaxation & 233 & 54.8 \\
Meditation & 112 & 26.4 \\
Reading & 8 & 1.9 \\
For Work & 28 & 6.6 \\
For relaxation and meditation & 28 & 6.6 \\
For relaxation, meditation, and work & 16 & 3.8 \\
\hline
\end{tabular}

Table III shows patients' perception on operating theatre background music. Two hundred and seventy-three (64.2\%) respondents preferred to listen to music in operating theatre while $96(22.6 \%)$ had no such preference. One hundred and forty-four $(33.9 \%)$ respondents asserted that they would love to listen to music in theatre during surgery, 54 (12.7\%) preferred just after surgery, and 92 (21.6\%) preferred listening to background music on all the occasions. Out of the 425 respondents, only $43(10.1 \%)$ affirmed that there was presence of background operating theatre music during their last surgery, while $236(55.5 \%)$ asserted that there was no 
background music during their last surgery.

TABLE III: PATIENTS' PERCEPTION ON OPERATING THEATRE BACKGROUND MUSIC $(\mathrm{N}=425)$

\begin{tabular}{|c|c|c|}
\hline Variables & Frequency & Percentage \\
\hline \multicolumn{3}{|c|}{$\begin{array}{l}\text { Prefer to listen to music in operating } \\
\text { theatre }\end{array}$} \\
\hline Yes & 273 & 64.2 \\
\hline No & 96 & 22.6 \\
\hline Don't know & 56 & 13.2 \\
\hline \multicolumn{3}{|c|}{$\begin{array}{l}\text { When preferred to listen to music in } \\
\text { operating theatre }\end{array}$} \\
\hline Just before surgery & 57 & 13.4 \\
\hline During the surgery & 144 & 33.9 \\
\hline Just after the surgery & 54 & 12.7 \\
\hline All of the above & 92 & 21.6 \\
\hline None of the above & 78 & 18.4 \\
\hline \multicolumn{3}{|c|}{$\begin{array}{l}\text { Presence of background operating } \\
\text { theatre music during last surgery }\end{array}$} \\
\hline Yes & 43 & 10.1 \\
\hline No & 236 & 55.5 \\
\hline Can't remember & 73 & 17.2 \\
\hline Not surgery done before & 73 & 17.2 \\
\hline
\end{tabular}

\section{DISCUSSION}

Almost two-third of the respondents were females, and most of them were between 25 and 40 years of age. Almost all respondents loved listening to music at home, and hymn and other soft music formed the dominant preference of respondents. This is understandable as the study was carried out in a predominant Christian setting. The pool of opinion of respondents about the usefulness of music showed assertions like - for relaxation, meditation, reading, and for work - in descending other of frequency. The opinion of our respondents is similar to previous studies as some beneficial effect of music has resulted in its application in almost every sphere of human endeavour. Positive effect of music on pain relief, relaxation, and labour for expectant mothers has also been reported [36]-[38]. A study investigated the impact of different types of music (grunge rock, classical, new age and designer) and found significant increase in caring, relaxation, mental clarity and vigour associated with music designed for specific purposes [39].

A certain researcher reported a proportional increase in eating behaviour following increase in the tempo of music among a people who were unaware that such study was being done [40]. Music has been used in the intensive care setting among patients with some reported beneficial effects [41]. Also listening to certain kind of music has been associated to lowering the systolic blood pressure among hypertensives, thereby emphasizing the beneficial effect of music therapy [42]. A meta-analysis indicated that some endoscopy patients had significantly improved pain score and significantly reduced anxiety following use of music, except for patient who had colposcopy and bronchoscopy [43]-[45].

Most respondents would prefer listening to background music in theatre while being operated on. The implication of this is that background music could be used in our operating theatres to draw from the benefits thereof, since most patients have preference for it. There were varied expressions of preference for timing in theatre for listening to background music, with some preferring music in all three phases of the operation - before, during and after surgery. Less than a quarter of respondents actually listened to background music in their last surgery. This means that we are currently not utilizing background music in operating theatre for our patients.

Limitation of this study is that it was carried out in a hospital setting with a convenience sampling method. A study done among members of the public will further inform on the shape public opinion regarding the use of background music in operating theatre.

Patients in our environment generally love listening to music for several reasons and were aware of the use of music for relaxation among others. Majority were desirous of the use of music in the operating theatre, while a few others thought otherwise. It seems reasonable to observe from the pool of patients' opinion in this study, that use of operating theatre background music do hold some promise and can be explored for the benefit of the patients.

\section{ACKNOWLEDGMENT}

We acknowledge the contributions of the surgery departmental ward and clinic nurses of the hospital (University of Port Harcourt Teaching Hospital) who graciously helped with some sample collection for the study.

\section{ETHICAL CONSIDERATIONS}

The approval of the research ethics committee of the University of Port Harcourt Teaching Hospital (UPTH) and the Rivers State University Teaching Hospital (RSUTH) were obtained before commencement of study.

\section{FUNDING}

The Study was privately sponsored by the researchers.

\section{CONFLICT OF INTEREST}

None declared.

\section{REFERENCES}

[1] Aldridge D. Music therapy: Performances and narratives Musictherapy World, Research News. 2000;1.

[2] Shiloah A. Jewish and Muslim traditions of music therapy. Music as Medicine: Routledge; 2017. p. 69-83.

[3] Brown S, Volgsten U. Music and manipulation: On the social uses and social control of music: Berghahn Books; 2005.

[4] Mundy LS, Wilkens D, Sanini C, Neff R, Rolfe J. System and method for using a list of audio media to create a list of audiovisual media. Google Patents; 2014.

[5] Wall M, Duffy A. The effects of music therapy for older people with dementia. British journal of nursing. 2010;19(2):108-13.

[6] Skingley A, Vella-Burrows T. Therapeutic effects of music and singing for older people. Nursing standard. 2010;24(19).

[7] Young S. Lullaby light shows: Everyday musical experience among under-two-year-olds. International Journal of Music Education. 2008;26(1):33-46.

[8] Brand M. Lullabies that awaken musicality in infants. Music Educators Journal. 1985;71(7):28-31.

[9] Wilson K. Black Bands and Black Culture: A Study of Black Military Bands in the Union Army during the Civil War. Australasian Journal of American Studies. 1990;9(1):31-7.

[10] Sullivan JM. Music for the injured soldier: A contribution of American women's military bands during World War II. Journal of Music Therapy. 2007;44(3):282-305. 
[11] Kim H. Military band musicians on the border: crossing over musical genres in the transnational space of the Korean War: University of Illinois at Urbana-Champaign; 2013.

[12] Devine K. The popularity of religious music and the religiosity of popular music. Scottish Music Review. 2011;2(1).

[13] Devine J. A ministry for the Word: An interview with Timothy DudleySmith, FHS. The Hymn. 2010;61(3):27.

[14] Jones D. Worship Styles in the Christian Church. Handbook for Sound Engineers. 2015:257.

[15] Hicks-Moore SL. Relaxing music at mealtime in nursing homes. Journal of gerontological nursing. 2005;31(12):26-32.

[16] Gopi D, Preetha A. Effectiveness of music therapy on depressive symptoms among elderly in selected geriatric homes. International Journal of Nursing Education. 2016;8(3):163-6.

[17] Pearce PL. Australian music and Aussie team sports: how the experience economy and the score interact. Music Business and the Experience Economy: Springer; 2013. p. 175-88.

[18] Young MA. Cultural performances of German national identity: Popular music, body culture, and the 2006 FIFA World Cup: Indiana University; 2013.

[19] Poku Quan-Baffour K. The power of Akan folk music in teaching adults1 about HIV/AIDS in Ghana. Muziki. 2007;4(2):209-23.

[20] Brandellero A, Janssen S, Cohen S, Roberts L. Popular music heritage, cultural memory and cultural identity. Taylor \& Francis; 2014.

[21] Hayward P. A place in the world: globalization, music, and cultural identity in contemporary Vanuatu. Music and globalization: critical encounters. 2011:52.

[22] Spracklen K. Nazi punks folk off: leisure, nationalism, cultural identity and the consumption of metal and folk music. Leisure Studies. 2013;32(4):415-28.

[23] O'hagin IB, Harnish D. Music as a cultural identity: a case study of Latino musicians negotiating tradition and innovation in northwest Ohio. International Journal of Music Education. 2006;24(1):56-70.

[24] Ekstrand D. The four human temperaments. Retrieved on. 2015;20.

[25] Johnson SL, editor Paul Hindemith's Philosophy of Music and the Role of The Four Temperaments. College Music Symposium; 2011: JSTOR.

[26] Harmon L, Troester K, Pickwick T, Pelosi G. The effects of different types of music on cognitive abilities. Journal of Undergraduate Psychological Research. 2008;3:41-6.

[27] Apel W. The Harvard dictionary of music: Harvard University Press; 2003.

[28] Lehmann JA, Seufert T. The influence of background music on learning in the light of different theoretical perspectives and the role of working memory capacity. Frontiers in psychology. 2017;8:1902.

[29] Areni CS, Kim D. The influence of background music on shopping behavior: classical versus top-forty music in a wine store. ACR North American Advances. 1993.
[30] Garlin FV, Owen K. Setting the tone with the tune: A meta-analytic review of the effects of background music in retail settings. Journal of business research. 2006;59(6):755-64.

[31] Watkins GR. Music therapy: proposed physiological mechanisms and clinical implications. Clinical nurse specialist. 1997;11(2):43-50.

[32] Yamasaki A, Booker A, Kapur V, Tilt A, Niess H, Lillemoe KD, et al. The impact of music on metabolism. Nutrition. 2012;28(11-12):107580.

[33] Nelson A, Hartl W, Jauch K-W, Fricchione GL, Benson H, Warshaw $\mathrm{AL}$, et al. The impact of music on hypermetabolism in critical illness. Current Opinion in Clinical Nutrition \& Metabolic Care. 2008;11(6):790-4.

[34] Sutoo De, Akiyama K. Music improves dopaminergic neurotransmission: demonstration based on the effect of music on blood pressure regulation. Brain research. 2004;1016(2):255-62.

[35] Salimpoor VN, Zatorre RJ. Neural interactions that give rise to musical pleasure. Psychology of Aesthetics, Creativity, and the Arts. 2013;7(1):62.

[36] Curtis SL. The effect of music on pain relief and relaxation of the terminally ill. Journal of Music Therapy. 1986;23(1):10-24.

[37] Hanser SB, Larson SC, O'Connell AS. The effect of music on relaxation of expectant mothers during labor. Journal of Music Therapy. 1983;20(2):50-8.

[38] Sin WM, Chow KM. Effect of music therapy on postoperative pain management in gynecological patients: a literature review. Pain Management Nursing. 2015;16(6):978-87.

[39] McCraty R, Barrios-Choplin B, Atkinson M, Tomasino D. The effects of different types of music on mood, tension, and mental clarity. Alternative therapies in health and medicine. 1998;4(1):75-84.

[40] Roballey TC, McGreevy C, Rongo RR, Schwantes ML, Steger PJ, Wininger MA, et al. The effect of music on eating behavior. Bulletin of the Psychonomic Society. 1985;23(3):221-2.

[41] O'Sullivan RJ. A musical road to recovery: music in intensive care. Intensive Care Nursing. 1991;7(3):160-3.

[42] Teng X, Wong MYM, Zhang Y-T, editors. The effect of music on hypertensive patients. 2007 29th Annual International Conference of the IEEE Engineering in Medicine and Biology Society; 2007: IEEE.

[43] Wang MC, Zhang LY, Zhang YL, Zhang YW, Xu XD, Zhang YC Effect of music in endoscopy procedures: systematic review and metaanalysis of randomized controlled trials. Pain medicine. 2014;15(10):1786-94.

[44] Palakanis KC, DeNobile JW, Sweeney WB, Blankenship CL. Effect of music therapy on state anxiety in patients undergoing flexible sigmoidoscopy. Diseases of the colon \& rectum. 1994;37(5):478-81.

[45] Cooke M, Chaboyer W, Schluter P, Hiratos M. The effect of music on preoperative anxiety in day surgery. Journal of advanced nursing. 2005;52(1):47-55. 